\title{
Expression of CD117 (c-kit) receptor in dysgerminoma of the ovary: diagnostic and therapeutic implications
}

\author{
Michael Sever ${ }^{1}$, Timothy D Jones ${ }^{1}$, Lawrence M Roth ${ }^{1}$, Fadi W Abdul Karim², Wenxin \\ Zheng $^{3}$, Helen Michael ${ }^{1}$, Eyas M Hattab ${ }^{1}$, Robert E Emerson ${ }^{1}$, Lee Ann Baldridge ${ }^{1}$ \\ and Liang Cheng ${ }^{1}$
}

${ }^{1}$ Department of Pathology and Laboratory Medicine, Indiana University, Indianapolis, IN, USA; ${ }^{2}$ Department of Pathology, Case Western Reserve University, Cleveland, OH, USA and ${ }^{3}$ Department of Pathology, Yale University, New Haven, CT, USA

\begin{abstract}
The proto-oncogene c-kit encodes a tyrosine kinase receptor, c-kit (CD117), which has been implicated in the development of a number of human malignancies. While the preferential expression of this protein has been well documented in testicular seminomas, there is little data concerning its expression in dysgerminomas of the ovary. We examined the expression of c-kit in $\mathbf{3 0}$ cases of ovarian dysgerminomas using immunohistohemical staining with a polyclonal anti-CD117 antibody. Staining was graded in a semiquantitative manner as follows: negative (no staining), $1+(1-10 \%$ staining), $2+(10-29 \%$ staining), $3+(30-50 \%$ staining $)$, or $4+(>50 \%$ staining). Of the 30 cases examined, 26 (87\%) demonstrated immunoreactivity for CD117. In total, 10 (33\%) demonstrated $4+$ staining; $9(30 \%)$ demonstrated $3+$ staining; 3 (10\%) demonstrated $2+$ staining; 4 (13\%) demonstrated 1 + staining; and 4 (13\%) demonstrated no staining. In conclusion, CD117 immunoreactivity was detected in $\mathbf{8 7 \%}$ of ovarian dysgerminomas, a finding that correlates with previously reported frequencies of CD117 expression in seminomas (78-100\%). Thus, antibodies to c-kit may be a useful diagnostic marker for ovarian dysgerminoma. Although the prognosis of patients with dysgerminoma is generally good, this receptor could potentially serve as a target for site-specific immunotherapy as an alternative and/or complement to conventional treatment options.
\end{abstract}

Modern Pathology (2005) 18, 1411-1416. doi:10.1038/modpathol.3800463; published online 22 July 2005

Keywords: ovary; germ cell tumors; c-kit (CD117); differential diagnosis; OCT4; dysgerminoma

The proto-oncogene $c$-kit encodes a 145-160 kDa, type III transmembrane tyrosine kinase receptor known as c-kit or CD117, ${ }^{1,2}$ which belongs to the same family of receptors as platelet-derived growth factor and colony-stimulating factor- $1 .{ }^{3}$ The binding of stem cell factor, the ligand for this receptor, leads to the dimerization of c-kit proteins, thus initiating a signaling cascade that ultimately induces cell growth. ${ }^{1}$ Expression of c-kit is essential in the development of some cell types, including melanocytes, germ cells, mast cells, erythrocytes, and interstitial cells of Cajal. ${ }^{1,4-6}$ In addition, expression of this receptor may be seen in other histologically

Correspondence: Dr L Cheng, MD, Department of Pathology and Laboratory Medicine, Indiana University Medical Center, University Hospital, Room 3465, 550 North University Boulevard, Indianapolis, IN 46202, USA.

E-mail: lcheng@iupui.edu

Received 28 December 2004; revised 31 May 2005; accepted 1 June 2005; published online 22 July 2005 normal cell types, such as breast epithelial cells, renal tubule cells, astrocytes, Purkinje cells, parotid acini, and endometrial cells. ${ }^{6-8}$ Aberrant expression of this receptor, however, has been implicated in the development of a number of human cancers, including malignancies of the lung, skin, breast, uterus, endometrium, urinary bladder, and ovary, as well as in certain types of leukemia, Ewing tumor, gastrointestinal stromal tumors (GISTs), and germ cell tumors. ${ }^{8-28}$ The advent of therapies targeted to c-kit have proven highly effective in treating some cancers that overexpress this receptor, such as chronic myeloid leukemia and GISTs. ${ }^{29-32}$

Dysgerminoma is an uncommon primitive germ cell tumor of the ovary, comprising $0.5-5 \%$ of all ovarian malignancies. ${ }^{33-37}$ This tumor is histologically and biologically similar to testicular seminoma. Accurate diagnosis of dysgerminoma is important as its treatment and prognosis differ significantly from those of other ovarian tumors. ${ }^{36,38-41}$ Thus, an immunohistochemical marker 
sensitive for this type of tumor could serve as a useful diagnostic tool. While current therapeutic regimens consisting of chemotherapy and radiation are highly effective in eradicating the disease, ${ }^{41,42}$ reproductive compromise is a common side effect of treatment and is a major concern given the young age at which this tumor typically presents. The identification of cellular proteins, such as c-kit, that may be overexpressed in this tumor could potentially lead to targeted therapies with less devastating side effects. While aberrant expression of c-kit has been well documented in testicular seminoma, ${ }^{2,5,11,13,14,43-46}$ little data concerning its expression in ovarian dysgerminoma are available. Therefore, we analyzed the immunohistochemical expression of c-kit in 30 cases of dysgerminoma of the ovary.

\section{Materials and methods}

In all, 30 cases of dysgerminoma of the ovary accessioned from 1982 to 2002 were retrieved from the surgical pathology files of three institutions: Indiana University Medical Center (Indianapolis, IN, USA), University Hospitals of Cleveland (Cleveland, $\mathrm{OH}, \mathrm{USA}$ ), and Yale University (New Haven, CT, USA). Medical records for the cases were reviewed. Formalin-fixed paraffin-embedded tissue specimens were available for all cases. Sections ( $4 \mu \mathrm{m}$ thick) were cut from paraffin blocks and stained with hematoxylin and eosin for microscopic examination. Pathologic staging was performed according to the FIGO staging system for ovarian neoplasms. ${ }^{47}$ This research was approved by the Institutional Review Boards in accordance with the Institutional Committee for the Protection of Human Subjects (Figure 1).

Additional paraffin sections of selected blocks were obtained for immunohistochemical studies, which were performed on an automated immunostainer. Immunohistochemical staining was performed with the avidin-biotin complex method of Hsu et $a l^{48,49}$ In brief, serial $4-\mu \mathrm{m}$-thick sections of formalin-fixed, paraffin-embedded tissue samples were used for the studies. Slides were deparaffinized twice in xylene for $5 \mathrm{~min}$ and rehydrated through graded ethanol solutions to distilled water. Antigen retrieval was performed by heating sections in citrate buffer (DAKO Target Retrieval Solution S1699, DAKO corporation, Carpinteria, CA, USA) for $15 \mathrm{~min}$. Inactivation of endogenous peroxidase activity was achieved by incubation in $3 \% \mathrm{H}_{2} \mathrm{O}_{2}$ for $15 \mathrm{~min}$. Nonspecific binding sites were bound using Protein Block (DAKO) for 20 min. Tissue sections were then incubated with the purified rabbit polyclonal antibody against the C-terminus of the p145 human c-kit protein (IgG, 1:50 dilution; Oncogene, Boston, MA, USA) for $30 \mathrm{~min}$ at room temperature. This was followed by biotinylated secondary antibody (DAKO) and peroxidase-labeled streptavidin.
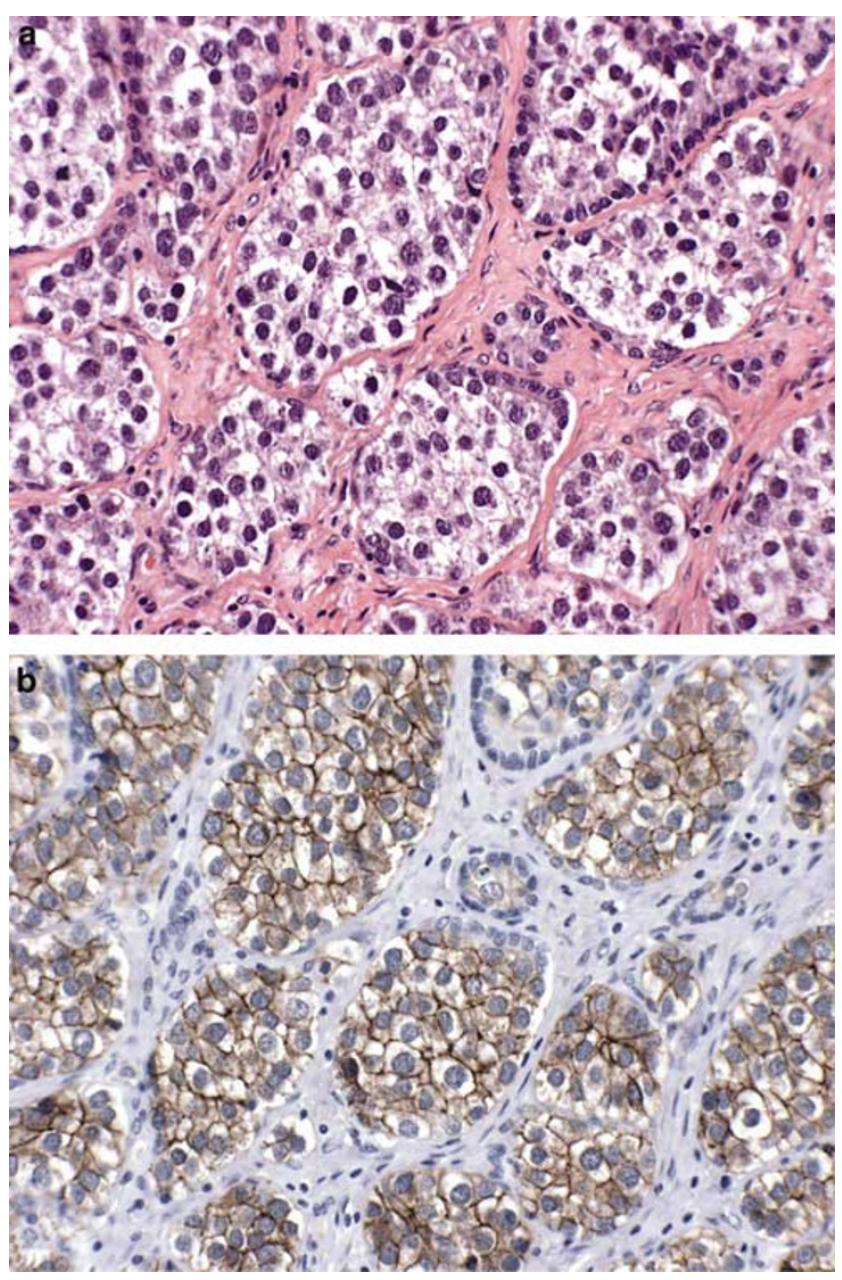

Figure 1 Dysgerminoma of the ovary (a). Positive membranous c-kit immunostaining was noted (b).

The chromogen 3,3-diaminobenzidine was used in the presence of hydrogen peroxide. Sections from GISTs were used as positive controls. Negative controls were performed using blocking serum in place of primary antibody. Positive and negative controls were run in parallel with each batch, and appropriate results were obtained.

The expression of c-kit was evaluated in a semiquantitative manner as follows: no staining (0), $1-10 \%$ staining $(1+), 11-29 \%(2+), 30-50 \%$ $(3+)$, and greater than $50 \%(4+)$. Given that c-kit is a membrane-bound tyrosine kinase receptor, only membranous staining pattern was considered positive. ${ }^{50}$

\section{Results}

The 30 patients examined had a mean age of 22 years (range of $6-50$ years). In all, 21 of the patients $(70 \%)$ presented with stage Ia or Ib disease; two $(7 \%)$ presented with stage IIa disease; and seven $(23 \%)$ presented with more advanced disease (stage 
IIIb or IIIc). Five of the patients (17\%) were found to have lymph node metastasis at presentation. Tumor sizes ranged from 2.5 to $21 \mathrm{~cm}$ in greatest dimension. Of 30 cases, $26(87 \%)$ demonstrated positive staining with antibodies to c-kit. In all, $10(33 \%)$ showed diffuse staining ( $>50 \%$ ), while nine $(30 \%)$ demonstrated $30-50 \%$ staining. Three cases $(10 \%)$ showed $11-29 \%$ staining and four cases $(13 \%)$ showed 1$10 \%$ staining. Only four of 30 cases $(13 \%)$ were immunohistochemically negative for c-kit. There was no statistically significant correlation between c-kit staining and pathologic stage or tumor size, as summarized in Table 1. Two lymph nodes from two patients with metastatic disease demonstrated strong c-kit reactivity.

\section{Discussion}

The expression of c-kit (CD117) has been demonstrated in a wide variety of human malignancies, including those of the lung, breast, endometrium, gastrointestinal tract, urinary bladder, and hematopoietic system. ${ }^{1,2,4-15,17-28,43-46}$ In addition, c-kit has also been shown to be overexpressed in specific types of malignant germ cell tumors, such as seminoma. ${ }^{2,5,11,13,14,43-46}$ Dysgerminoma of the ovary is a neoplasm that is histologically, biologically, and clinically similar to testicular seminoma. While, the immunohistochemical expression of the transmembrane receptor c-kit in seminoma has been well documented, its expression in dysgerminoma has not been extensively explored. In this study, we analyzed 30 cases of ovarian dysgerminoma with anti-c-kit antibodies and found that, like seminoma, these tumors frequently (87\%) exhibit immunoreactivity for c-kit.

The accurate diagnosis of dysgerminoma is of critical importance as the therapy and prognosis for these patients is significantly different from that of other ovarian malignancies. ${ }^{37}$ Dysgerminoma has a better prognosis than other malignant ovarian tumors, as it is highly sensitive to cisplatin- or carboplatin-based chemotherapy and to radiotherapy. ${ }^{39,42,51,52}$ Cure rates approach $95 \%$ with treatment strategies employing adjuvant chemotherapy, even in advanced metastatic disease. ${ }^{14,33-41}$

Histologically, the differential diagnosis for dysgerminoma includes other germ cell tumors, most notably the solid variants of yolk sac tumor and embryonal carcinoma, as well as clear-cell adenocarcinoma, granulosa cell tumor, lymphoma, and metastatic tumors, such as melanoma. Immunohistochemical stains can often aid in discriminating between these morphologically similar lesions. Immunostaining for placental-like alkaline phosphatase in the ovary, although relatively specific for dysgerminoma, can show positivity in other types of primitive germ cell tumors, as well as in benign germ cells. ${ }^{53}$ Cytokeratins can show focal staining in dysgerminoma. ${ }^{54}$ OCT4 has recently been shown to be a sensitive and relatively specific biomarker for the detection of dysgerminoma, although focal staining in clear-cell adenocarcinoma has been noted. ${ }^{55}$ Likewise, stains for c-kit may prove to be a useful diagnostic tool in histologically difficult cases of dysgerminoma.

Previous studies demonstrating expression of ckit in ovarian tumors, let alone dysgerminoma in particular, have included only small numbers of cases. In a broad study of c-kit expression in numerous tumors, Went et al demonstrated that dysgerminoma (two cases) and gonadoblastoma (one case) both demonstrate c-kit expression. Additionally, Brenner tumor (33\% staining), cervical adenocarcinoma (33\% staining), and, less frequently, ovarian carcinoma, cervical squamous carcinoma, and vulvar carcinoma all demonstrate minimal c-kit expression. ${ }^{50}$ Klein et $a l^{56}$ demonstrated the lack of c-kit expression in ovarian mesenchymal tumors, including leiomyosarcoma, carcinosarcoma, endometrial stromal tumors and clear-cell ovarian sarcoma. Similarly, Raspollini et a ${ }^{57}$ demonstrated that $51 \%$ of advanced ovarian serous carcinoma demonstrated c-kit expression. Schmandt et al ${ }^{9}$ found that low-grade serous carcinoma of the ovary demonstrated no c-kit expression, and only $26 \%$ of highgrade serous tumors showed some reactivity. Ramalingam et $a l^{58}$ recently reported that yolk sac tumors of the ovary, often included in the differential diagnosis of dysgerminoma, demonstrated no c-kit expression.

Natali et $a l^{6}$ investigated c-kit expression in a number of benign and malignant neoplasms using immunohistochemistry, including a single case of dysgerminoma, which was found to be immunoreactive for c-kit. Tsuura et $a l^{5}$ similarly investigated c-kit expression in 884 solid tumors and found c-kit positivity in three of four $(75 \%)$ dysgerminomas. Sakuma et $a l^{59}$ studied 16 intracranial germinomas and found membranous c-kit immunoreactivity in the majority of tumor cells from all cases.

Our study of 30 cases of ovarian dysgerminoma is, to our knowledge, the largest series of cases to be analyzed for c-kit expression. Our finding of c-kit positivity in $87 \%$ of dysgerminoma suggests that this marker may serve as a useful marker for dysgerminoma, especially when other germ cell tumors and clear-cell adenocarcinoma fall in the differential diagnosis.

Those cases that failed to exhibit c-kit expression may actually represent heterologous expression of the receptor in each tumor or variance among individuals. Review of the hematoxylin and eosinstained sections revealed no morphologic qualities that served as a predictor of c-kit status, although areas of necrosis did fail to highlight with the antibody. Technical inadequacy may also serve as a less likely explanation. The stage of disease at presentation, too, was not a statistically significant predictor of c-kit expression. Of the cases that failed to show c-kit reactivity, all demonstrated strong 
OCT4 expression, as reported previously, which may serve as an alternative marker in those cases that fail to show c-kit reactivity. ${ }^{55}$ We should emphasize that OCT4 is also positive in embryonal carcinoma and clear-cell adenocarcinoma of the ovary; ${ }^{55,60-62}$ therefore, its utility in the differential diagnosis of these tumors is limited. Furthermore, embryonal carcinoma has been noted to rarely demonstrate c-kit expression. ${ }^{44}$

With the advent of c-kit-targeted therapy with imatinib mesylate (Gleevec; Novartis), and the proven success of this drug in the treatment of chronic myelogenous leukemia (CML) and GIST, ${ }^{29-32}$ c-kit expression may no longer be merely of diagnostic relevance but may also have therapeutic significance. Anti-c-kit compounds have been shown in in vitro and in vivo studies to inhibit effectively receptor autophosphorylation and subsequent MAP kinase activity and Akt activation. ${ }^{16}$ The responsiveness of tumors to imatinib mesylate has been shown to correlate with specific $c$-kit gene mutations rather than with immunohistochemical expression. ${ }^{50,63}$ Therefore, c-kit positivity on immunostaining does not necessarily indicate that a patient's tumor will respond to therapy targeted against c-kit. A number of $c$-kit mutations have been identified in GISTs in exons 9, 11, 13, and 17, resulting in a protein product with constitutive kinase activity. ${ }^{15,16,64,65}$ Tian et $a l^{2}$ discovered a novel missense mutation (D816H) in the phosphotransferase domain of the $c$-kit gene in tumors of seminoma/ dysgerminoma type, providing the first evidence that the c-kit signal transduction cascade may be important in the pathogenesis of these neoplasms as well. Subsequently, Przygodzki et $a l^{66}$ and Sakuma et $a l^{43}$ identified $c$-kit gene mutations in primary mediastinal seminomas and testicular seminomas, respectively. Kemmer et $a l^{67}$ examined the frequency and spectrum of $c$-kit gene mutations in 54 testicular seminomas, one ovarian dysgerminoma, and 37 nonseminomatous germ cell tumors and found $c$-kit mutations in $26 \%$ of seminomas. Neither the single dysgerminoma nor any of the nonseminomatous germ cell tumors harbored a $c$-kit gene mutation. Given the histologic, biologic, and immunohistochemical similarities between seminoma and dysgerminoma, it is reasonable to speculate that some $c$-kit mutations would be discovered in dysgerminoma if more than one case were analyzed. In fact, Pauls and associates ${ }^{68}$ studied the expression and mutational status of a pure dysgerminoma and found an exon 17 D816V mutation in the $c$-kit gene and strong immunohistochemical c-kit expression. Sakuma et $a l^{59}$ analyzed 16 intracranial germinomas and found $c$-kit gene mutations in four cases $(25 \%)$. While $c$-kit mutations have been found in dysgerminomas, it is not clear if these mutations make these tumors amenable to treatment with anti-c-kittargeted therapies.

Dysgerminoma is highly radiosensitive, and cure rates approach $95 \%$ with adjuvant chemotherapy, even in advanced metastatic disease. ${ }^{51}$ Reproductive difficulties following treatment are a common adverse side effect. ${ }^{33}$ Therefore, current therapeutic development has focused on reduction in morbidity with fertility-sparing treatments. ${ }^{33-41}$ This is often of great concern to patients with dysgerminoma given the young mean age at presentation. Given the successful treatment of CML and GIST with imatinib mesylate, anti-c-kit compounds could prove to be an additional treatment option in patients with dysgerminoma, allowing for conservative therapy with a potentially less-devastating impact on post-treatment fertility. It has been suggested, although not rigorously proven, that tumor resistance to carboplatin-based chemotherapy may result from exon 17 C-kit gene mutations. ${ }^{68}$ Similarly, Raspollini et $a l^{57}$ demonstrated that advanced ovarian carcinoma that expressed c-kit was resistant to current chemotherapeutic regimens.

Dysgerminoma is a relatively rare malignant germ cell tumor of the ovary seen in young adults. In this study, we demonstrate that $87 \%$ of these tumors exhibit immunohistochemical expression of the transmembrane tyrosine kinase receptor c-kit (CD117), much like its male counterpart, seminoma. Thus, immunostains for c-kit may be potentially useful in distinguishing between dysgerminoma and other ovarian neoplasms. With the advent and success of c-kit-directed therapies in chronic myeloid leukemia and GIST, c-kit expression in dysgerminoma may provide a new target for conservative, fertility-sparing therapy.

\section{References}

1 Vliagoftis H, Worobec AS, Metcalfe DD. The protooncogene c-kit and c-kit ligand in human disease. J Allergy Clin Immunol 1997;100:435-440.

2 Tian Q, Frierson Jr HF, Krystal GW, et al. Activating $c$-kit gene mutations in human germ cell tumors. Am J Pathol 1999;154:1643-1647.

3 Yarden Y, Kuang WJ, Yang-Feng T, et al. Human protooncogene c-kit: a new cell surface receptor tyrosine kinase for an unidentified ligand. EMBO J 1987;6: 3341-3351.

4 Zsebo KM, Williams DA, Geissler EN, et al. Stem cell factor is encoded at the Sl locus of the mouse and is the ligand for the c-kit tyrosine kinase receptor. Cell 1990;63:213-224.

5 Tsuura Y, Hiraki H, Watanabe K, et al. Preferential localization of c-kit product in tissue mast cells, basal cells of skin, epithelial cells of breast, small cell lung carcinoma and seminoma/dysgerminoma in human: immunohistochemical study on formalin-fixed, paraffin-embedded tissues. Virchows Arch 1994;424: 135-141.

6 Natali PG, Nicotra MR, Sures I, et al. Expression of c-kit receptor in normal and transformed human nonlymphoid tissues. Cancer Res 1992;52:6139-6143.

7 Elmore LW, Domson K, Moore JR, et al. Expression of c-kit (CD117) in benign and malignant human endometrial epithelium. Arch Pathol Lab Med 2001;125: 146-151. 
8 Natali PG, Nicotra MR, Sures I, et al. Breast cancer is associated with loss of the c-kit oncogene product. Int J Cancer 1992;52:713-717.

9 Schmandt RE, Broaddus R, Lu KH, et al. Expression of c-ABL, c-KIT, and platelet-derived growth factor receptor-beta in ovarian serous carcinoma and normal ovarian surface epithelium. Cancer 2003;98: $758-764$.

10 Jorgensen N, Muller J, Jaubert F, et al. Heterogeneity of gonadoblastoma germ cells: similarities with immature germ cells, spermatogonia and testicular carcinoma in situ cells. Histopathology 1997;30:177-186.

11 Rajpert-De Meyts E, Skakkekbaek NE. Expression of the c-kit protein product in carcinoma-in-situ and invasive testicular germ cell tumors. Int J Androl 1994;17:85-92.

12 Kollmannsberger C, Mayer F, Pressler H, et al. Absence of c-KIT and members of the epidermal growth factor receptor family in refractory germ cell cancer. Cancer 2002;95:301-308.

13 Looijenga $\mathrm{LH}$, de Leeuw $\mathrm{H}$, van Oorschot $\mathrm{M}$, et al. Stem cell factor receptor (c-KIT) codon 816 mutations predict development of bilateral testicular germ-cell tumors. Cancer Res 2003;63:7674-7678.

14 Izquierdo MA, Van der Valk P, Van Ark-Otte J, et al. Differential expression of the c-kit proto-oncogene in germ cell tumours. J Pathol 1995;177:253-258.

15 Antonescu CR, Sommer G, Sarran L, et al. Association of KIT exon 9 mutations with nongastric primary site and aggressive behavior: KIT mutation analysis and clinical correlates of 120 gastrointestinal stromal tumors. Clin Cancer Res 2003;9:3329-3337.

16 Heinrich MC, Rubin BP, Longley BJ, et al. Biology and genetic aspects of gastrointestinal stromal tumors: KIT activation and cytogenetic alterations. Hum Pathol 2002;33:484-495.

17 Scobie JV, Acs G, Bandera CA, et al. C-kit immunoreactivity in endometrial adenocarcinomas and its clinicopathologic significance. Int J Gynecol Pathol 2003;22:149-155.

18 Rossi G, Cavazza A, Marchioni A, et al. Kit expression in small cell carcinomas of the lung: effects of chemotherapy. Mod Pathol 2003;16:1041-1047.

19 Burger H, den Bakker MA, Stoter G, et al. Lack of c-kit exon 11 activating mutations in C-KIT/CD117-positive SCLC tumour specimens. Eur J Cancer 2003;39: 793-799.

20 Naeem M, Dahiya M, Clark JI, et al. Analysis of c-kit protein expression in small-cell lung carcinoma and its implication for prognosis. Hum Pathol 2002;33: 1182-1187.

21 Micke P, Basrai M, Faldum A, et al. Characterization of c-kit expression in small cell lung cancer: prognostic and therapeutic implications. Clin Cancer Res 2003; 9:188-194.

22 Miettinen M, Sarlomo-Rikala M, Lasota J. KIT expression in angiosarcomas and fetal endothelial cells: lack of mutations of exan 11 and exan 17 of c-kit. Mod Pathol 2000;13:536-541.

23 Yamasaki T, Shimazaki H, Aida S, et al. Primary small cell (oat cell) carcinoma of the breast: report of a case and review of the literature. Pathol Int 2000;50: 914-918.

24 Akintola-Ogunremi O, Pfeifer JD, Tan BR, et al. Analysis of protein expression and gene mutation of c-kit in colorectal neuroendocrine carcinomas. Am J Surg Pathol 2003;27:1551-1558.
25 Potti A, Moazzam N, Ramar K, et al. CD117 (c-KIT) overexpression in patients with extensive-stage smallcell lung carcinoma. Ann Oncol 2003;14:894-897.

26 Scotlandi K, Manara MC, Strammiello R, et al. C-kit receptor expression in Ewing's sarcoma: lack of prognostic value but therapeutic targeting opportunities in appropriate conditions. J Clin Oncol 2003; 21:1952-1960.

27 Wang L, Felix JC, Lee JL, et al. The proto-oncogene c-kit is expressed in leiomyosarcomas of the uterus. Gynecol Oncol 2003;90:402-406.

28 Pan CX, Yang XJ, Lopez-Beltran A, et al. c-kit expression in small cell carcinoma of the urinary bladder: prognostic and therapeutic implications. Mod Pathol 2005;18:320-323.

29 Joensuu H, Roberts PJ, Sarlomo-Rikala M, et al. Effect of the tyrosine kinase inhibitor STI571 in a patient with a metastatic gastrointestinal stromal tumor. $\mathrm{N}$ Engl J Med 2001;344:1052-1056.

30 Mesters RM, Padro T, Bieker R, et al. Stable remission after administration of the receptor tyrosine kinase inhibitor SU5416 in a patient with refractory acute myeloid leukemia. Blood 2001;98:241-243.

31 O’Dwyer ME, Druker BJ. Chronic myelogenous leukaemia-new therapeutic principles. J Intern Med 2001; 250:3-9.

32 Heinrich MC, Griffith DJ, Druker BJ, et al. Inhibition of c-kit receptor tyrosine kinase activity by STI 571, a selective tyrosine kinase inhibitor. Blood 2000;96: 925-932.

33 Mitchell MF, Gershenson DM, Soeters RP, et al. The long-term effects of radiation therapy on patients with ovarian dysgerminoma. Cancer 1991;67: 1084-1090.

34 Zaghloul MS, Khattab TY. Dysgerminoma of the ovary: good prognosis even in advanced stages. Int J Radiat Oncol Biol Phys 1992;24:161-165.

35 LaPolla JP, Benda J, Vigliotti AP, et al. Dysgerminoma of the ovary. Obstet Gynecol 1987;69:859-864.

36 Gallion $\mathrm{HH}$, van Nagell Jr JR, Donaldson ES, et al. Ovarian dysgerminoma: report of seven cases and review of the literature. Am J Obstet Gynecol 1988;158:591-595.

37 Susnerwala SS, Pande SC, Shrivastava SK, et al. Dysgerminoma of the ovary: review of 27 cases. J Surg Oncol 1991;46:43-47.

38 Talerman A. Germ cell tumors of the ovary. Curr Opin Obstet Gynecol 1997;9:44-47.

39 Bjorkholm E, Lundell M, Gyftodimos A, et al. Dysgerminoma: the Radiumhemmet series 19271984. Cancer 1990;65:38-44.

40 Gordon A, Lipton D, Woodruff JD. Dysgerminoma: a review of 158 cases from the Emil Novak Ovarian Tumor Registry. Obstet Gynecol 1981;58:497-504.

41 Williams SD. Ovarian germ cell tumors: an update. Semin Oncol 1998;25:407-413.

42 De Palo G, Lattuada A, Kenda R, et al. Germ cell tumors of the ovary: the experience of the National Cancer Institute of Milan. I. Dysgerminoma. Int J Radiat Oncol Biol Phys 1987;13:853-860.

43 Sakuma Y, Sakurai S, Oguni S, et al. Alterations of the $c$-kit gene in testicular germ cell tumors. Cancer Sci 2003;94:486-491.

44 Leroy X, Augusto D, Leteurtre E, et al. CD30 and CD117 (c-kit) used in combination are useful for distinguishing embryonal carcinoma from seminoma. J Histochem Cytochem 2002;50:283-285. 
45 Bokemeyer C, Kuczyk MA, Dunn T, et al. Expression of stem-cell factor and its receptor c-kit protein in normal testicular tissue and malignant germ-cell tumours. J Cancer Res Clin Oncol 1996;122:301-306.

46 Strohmeyer T, Reese D, Press M, et al. Expression of the c-kit proto-oncogene and its ligand stem cell factor (SCF) in normal and malignant human testicular tissue. J Urol 1995;153:511-515.

47 Greene FL, Page DL, Fleming ID, et al. American Joint Committee on Cancer Staging Manual. Springer: New York, 2002.

48 Hsu SM, Raine L, Fanger H. The use of antiavidin antibody and avidin-biotin-peroxidase complex in immunoperoxidase techniques. Am J Clin Pathol 1981; 75:816-821.

49 Hsu SM, Raine L, Fanger H. Use of avidin-biotinperoxidase complex (ABC) in immunoperoxidase techniques: a comparison between $\mathrm{ABC}$ and unlabeled antibody (PAP) procedures. J Histochem Cytochem 1981;29:577-580.

50 Went PT, Dirnhofer S, Bundi M, et al. Prevalence of KIT expression in human tumors. J Clin Oncol 2004;22:4514-4522.

51 Williams SD, Blessing JA, Hatch KD, et al. Chemotherapy of advanced dysgerminoma: trials of the Gynecologic Oncology Group. J Clin Oncol 1991;9: 1950-1955.

52 Thomas GM, Dembo AJ, Hacker NF, et al. Current therapy for dysgerminoma of the ovary. Obstet Gynecol 1987;70:268-275.

53 Burke AP, Mostofi FK. Placental alkaline phosphatase immunohistochemistry of intratubular malignant germ cells and associated testicular germ cell tumors. Hum Pathol 1988;19:663-670.

54 Pesce M, Wang X, Wolgemuth DJ, et al. Differential expression of the Oct-4 transcription factor during mouse germ cell differentiation. Mech Dev 1998;71: 89-98.

55 Cheng L, Thomas A, Roth LM, et al. OCT4: a novel biomarker for dysgerminoma of the ovary. Am J Surg Pathol 2004;28:1341-1346.

56 Klein WM, Kurman RJ. Lack of expression of c-kit protein (CD117) in mesenchymal tumors of the uterus and ovary. Int J Gynecol Pathol 2003;22:181-184.
57 Raspollini MR, Castiglione F, Rossi Degl'innocenti D, et al. Tumour-infiltrating gamma/delta T-lymphocytes are correlated with a brief disease-free interval in advanced ovarian serous carcinoma. Ann Oncol 2005; 16:590-596.

58 Ramalingam P, Malpica A, Silva EG, et al. The use of cytokeratin 7 and EMA in differentiating ovarian yolk sac tumors from endometrioid and clear cell carcinomas. Am J Surg Pathol 2004;28:1499-1505.

59 Sakuma Y, Sakurai S, Oguni S, et al. c-kit gene mutations in intracranial germinomas. Cancer Sci 2004; 95:716-720.

60 Cheng L. Establishing a germ cell origin for metastatic tumors using OCT4 immunohistochemistry. Cancer 2005;101:2006-2010.

61 Jones TD, Ulbright TM, Eble JN, et al. OCT4 staining in testicular tumors: a sensitive and specific marker for seminoma and embryonal carcinoma. Am J Surg Pathol 2004;28:935-940.

62 Looijenga LH, Stoop H, de Leeuw HP, et al. POU5F1 (OCT3/4) identifies cells with pluripotent potential in human germ cell tumors. Cancer Res 2003;63:22442250.

63 Heinrich MC, Corless CL, Blanke CD. KIT mutational status predicts clinical response to STI571 in patients with metastatic gastrointestinal stromal tumors (GISTs). Proc Am Soc Clin Oncol 2002;20:1692-1703.

64 Lasota J, Wozniak A, Sarlomo-Rikala M, et al. Mutations in exons 9 and 13 of KIT gene are rare events in gastrointestinal stromal tumors. A study of 200 cases. Am J Pathol 2000;157:1091-1095.

65 Hirota S, Isozaki K, Moriyama Y, et al. Gain-of-function mutations of c-kit in human gastrointestinal stromal tumors. Science 1998;279:577-580.

66 Przygodzki RM, Hubbs AE, Zhao FQ, et al. Primary mediastinal seminomas: evidence of single and multiple KIT mutations. Lab Invest 2002;82:1369-1375.

67 Kemmer K, Corless CL, Fletcher JA, et al. KIT mutations are common in testicular seminomas. Am J Pathol 2004;164:305-313.

68 Pauls K, Wardelmann E, Merkelbach-Bruse S, et al. c-KIT codon 816 mutation in a recurrent and metastatic dysgerminoma of a 14-year-old girl: case study. Virchows Arch 2004;445:651-654 